\title{
The unique reactivity of "super silyl" in organic synthesis: A theoretical study
}

\author{
Matsujiro Akakura $^{a^{*}}$, Matthew B. Boxer ${ }^{b}$, and Hisashi Yamamoto ${ }^{b_{*}}$ \\ ${ }^{a}$ Department of Chemistry, Aichi University of Education, \\ Igaya-cho, Kariya 448-8542, Japan and ${ }^{\mathrm{b}}$ Department of Chemistry, \\ The University of Chicago, 5735 South Ellis Avenue, Chicago, \\ Illinois 60637 \\ E-mail: yamamoto@uchicago.edu
}

Dedicated to Professor Alain Krief on his $65^{\text {th }}$ birthday

\begin{abstract}
We recently developed a new use of the super silyl group in organic reactions, and showed that it has unique reactivity. One of the reactions using this reagent is diastereoselective Mukaiyama aldehyde cross-aldol reaction catalyzed by a highly active Brønsted acid. This reaction produced syn-1,3-diol derivatives with high yield and high stereoselectivity. Certain features and outcomes of the reaction were not clear, so we decided to investigate the reaction mechanism through a theoretical study. In this paper, structures of super silyl species were observed as the subject of study. First 1 and $\mathbf{2}$ were investigated so that the effect of a TMS group adjacent to a silicenium ion could be determined. Interestingly, it was found that the TMS group stabilized the silicenium ion. It is presumed that the stability of the tris(trimethylsilyl) silicenium ion (TTMSS+) is related to the unique reactivity of super silyl group in theses reactions. We also investigated equivalent structures of silyl enol ethers (SEE) and found an unusual structure of 5. This structure is a result of unusual interactions between the silyl portion and enol ether (EE) portion; 1) $\mathrm{C}=\mathrm{C}$ and $\mathrm{Si}-\mathrm{Si}$ bonds, 2) lone pair of oxygen and Si-Si bond.
\end{abstract}

Keywords: "Super silyl", Mukaiyama cross-aldol reaction, silicenium ion, silyl enol ether, theoretical study

\section{Introduction}

Mukaiyama aldol synthesis is one of the most powerful tools for cross-aldol reactions. ${ }^{1} \mathrm{We}$ recently reported the diastereoselective Mukaiyama cross-aldol reaction of aldehyde derived silyl enol ethers and aldehydes by using the functionality of the tris(trimethylsilyl)silyl (TTMSS) group, also called "super silyl" 2 and a highly active Brønsted acid (Scheme 1). ${ }^{3}$ This reaction 
generates hydroxy aldehydes in high yield and exceptionally high selectivity. We proposed a "Self-Repair" mechanism in that report, which shows that (TTMSS)NTf ${ }_{2}$ is produced through decomposition of the silyl enol ether (Scheme 2). Although there are numerous reports for Mukaiyama aldol reactions, this is the first example for generating the silyl protected hydroxy aldehyde with such efficiency and selectivity. The success is largely due to the super silyl group and reactive Brønsted acid initiator. This report looks at energies and conformations of model compounds associated with the proposed initiation sequence for this reaction. A comparison of an $\alpha$-silyl silicenium ion with an $\alpha$-alkyl silicenium ions as well as super silyl enol ethers models with TMS enol ethers was performed to gain insight into the plausibility of this mechanism and to evaluate the effect of the super silyl group. An interesting overlap of HOMO's on the super silyl enol ether was also observed and may help to explain the exceedingly unique selectivities observed with this substrate.
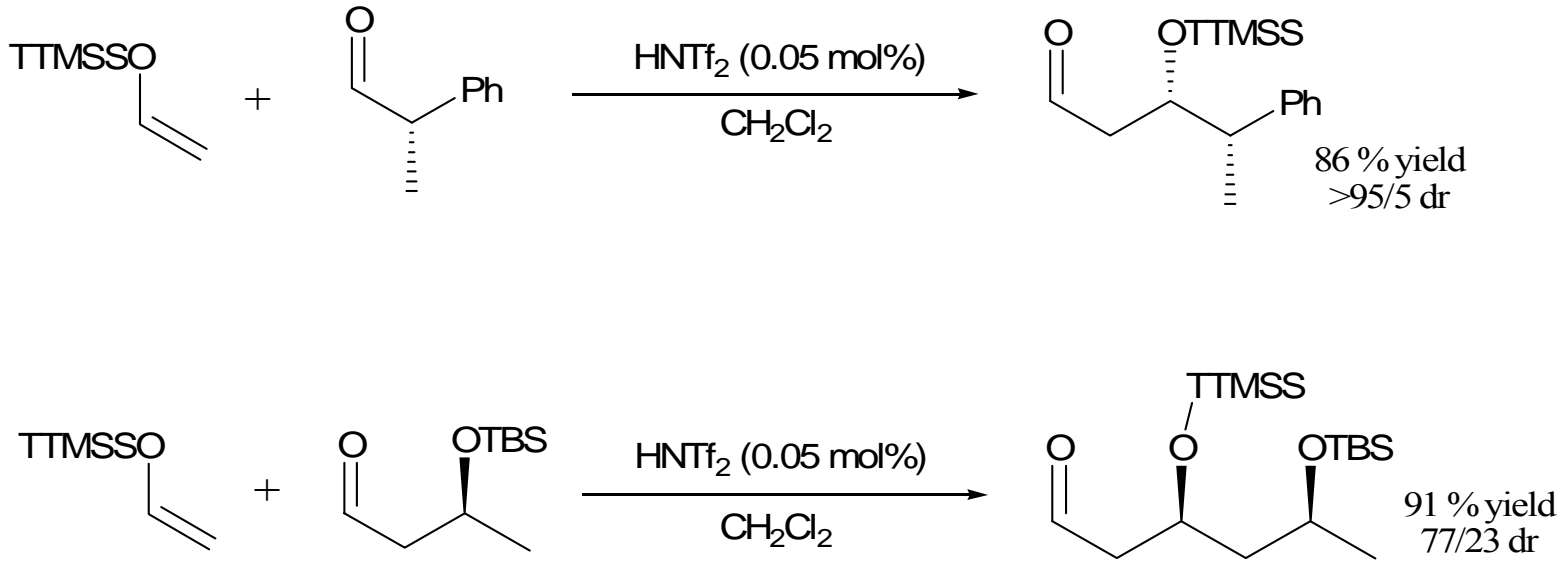

\section{Scheme 1}

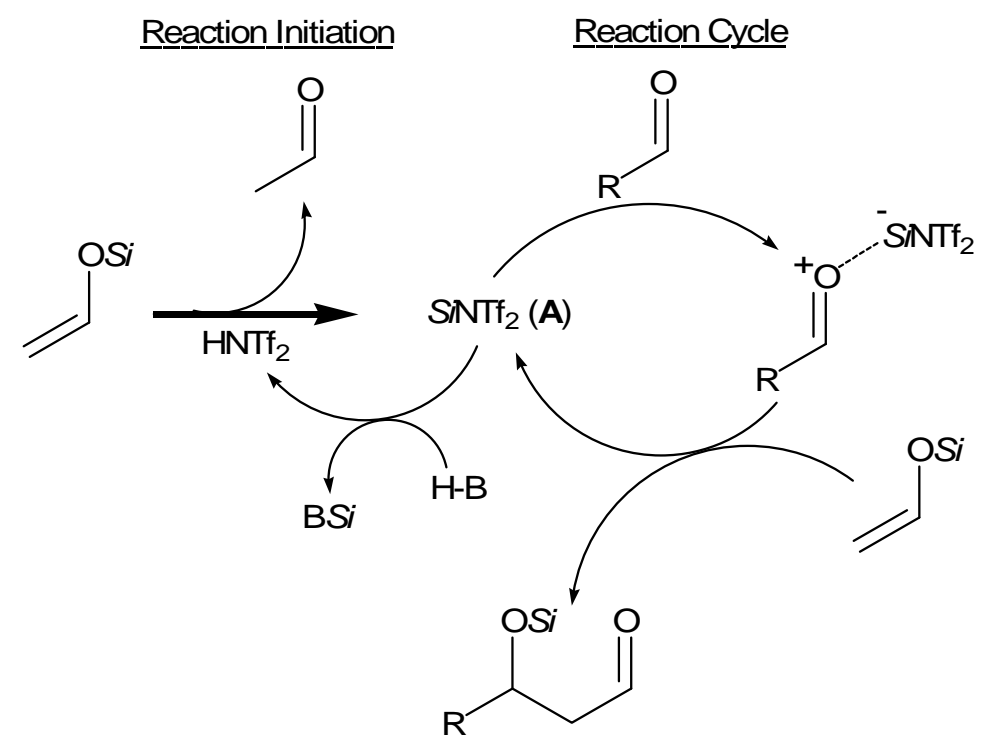

Scheme 2 


\section{Results and Discussion}

The first aspect we investigated was the stabilizing effect of the moiety adjacent to the silicenium ion (akin to $\mathbf{A}$ in Scheme 2). The simplest model was chosen for this purpose: one hydrogen atom of a $\mathrm{H}_{3} \mathrm{Si}^{+}$cation was substituted by a $t$-Bu group or a $\mathrm{Si}\left(\mathrm{CH}_{3}\right)_{3}$ group and the relative energy was considered. Importantly, there is not an overwhelming difference in the bulkiness of the groups when considering the $t$-Bu- and TMS-groups. The only significant difference is the atom connected to the cationic center atom (carbon vs. silicon). The results shown in Figure 1 indicate that the silicenium ion appended with the TMS group (2) is more stable than the one with the $t$-Bu group (1) due to the fact that the values of $\mathrm{SiH}_{3}{ }^{+}$and $\mathrm{SiH}_{4}$ remain the same in the two calculation formulas. That is, the silyl group at the $\alpha$-position has a net stabilizing effect on the silicenium ion. Interestingly, the $\mathrm{sp}^{3}$ hybrid structure of the central carbon of the $t$-Bu group in 1 changed while the structure of the TMS group in 2 preserved its $\mathrm{sp}^{3}$ hybrid structure. The aforementioned TMS stabilization effect of the $\alpha$-silicenium ion is interesting because in analogous carbocation structures, silyl group stabilization at the $\beta$-position is well-known, ${ }^{4}$ but there is a reported destabilization effect at the $\alpha$-position. ${ }^{5}$ The $\alpha$-silicenium ion stabilization likely arises from the higher polarizability of silicon and the hyperconjugation by $\mathrm{Si}-\mathrm{C}$ bonds in the TMS group. Therefore, the TTMSS cation is anticipated to be more stable than alkyl substituted silicenium ions supporting the generation and utility of this Lewis acid as shown in Scheme 2.
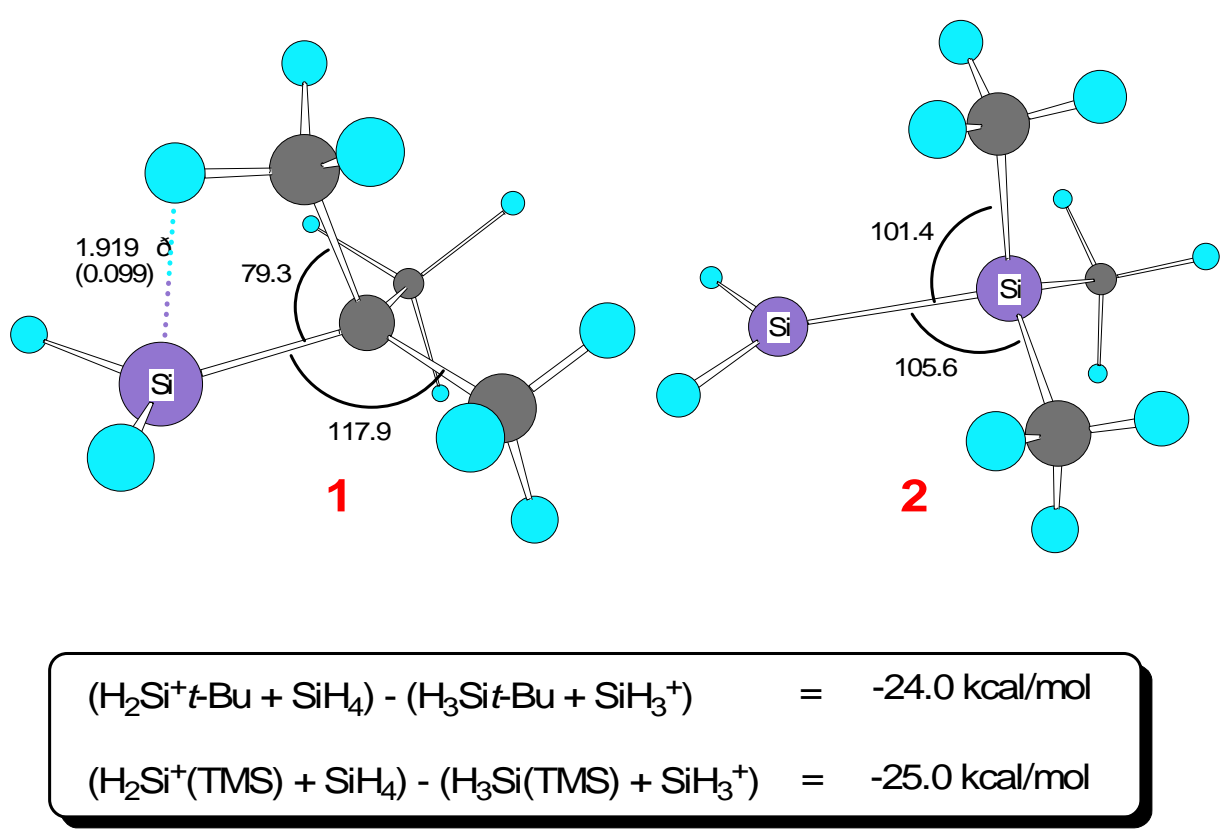

Figure 1. Structures of two silicenium ion models with $t$-Bu and TMS substituents. Energy difference $(\mathrm{kcal} / \mathrm{mol})$ between $\left(\mathrm{H}_{2} \mathrm{Si}^{+} \mathrm{R}+\mathrm{SiH}_{4}\right)$ and $\left(\mathrm{H}_{3} \mathrm{SiR}+\mathrm{SiH}_{3}{ }^{+}\right)$is indicated for estimation of the stabilities of the species. 
Next we investigated the stability of the super silyl enol ether model (5) and the TMS enol ether (6) as well as the cationic species generated after electrophilic reaction of these silyl enol ethers (3 and 4 respectively) to gain insight into the proposed reaction initiation event. Concerning 3 and 4, the $\mathrm{CH}_{3} \mathrm{CH}-\mathrm{O}$ (H-EE) portion is very similar in the two structures while the Si-O bond length and angle of the silyl groups $(\mathrm{A}(\mathrm{O}, \mathrm{Si}, \mathrm{C})$ and $\mathrm{A}(\mathrm{O}, \mathrm{Si}, \mathrm{Si}))$ have some differences (Figure 2). The longer $\mathrm{Si}-\mathrm{O}$ bond length and a smaller $\mathrm{A}(\mathrm{O}, \mathrm{Si}, \mathrm{Si})$ in 3 implies that the TTMSS group has a smaller interaction with $\mathrm{CH}_{3} \mathrm{CH}-\mathrm{O}$ than the TMS group, that is, the TTMSS group has more cationic property than the TMS group. This arises from the stability of TTMSS-cation species (vide supra). For both cationic species, $\mathrm{A}(\mathrm{O}, \mathrm{Si}, \mathrm{X} 1)(\mathrm{X}=\mathrm{C}$ or $\mathrm{Si})$ is larger than the other values of the angle $(\mathrm{A}(\mathrm{O}, \mathrm{Si}, \mathrm{X} 2)$ and $\mathrm{A}(\mathrm{O}, \mathrm{Si}, \mathrm{X} 3))$. The reason for this is the steric repulsion between $\mathrm{XH}_{3}$ in the silyl groups and $\mathrm{CH}$ of $\mathrm{H}$-EE. In reference to the stability of the species we calculated with the formulas in Figure 2: the energy difference of the total values $\left(\mathrm{H}-\mathrm{EE} \mathrm{S} 1^{+}+\right.$ $\mathrm{S}^{2}{ }^{+}$; S1, S2 = TMS or TTMSS) indicated that 3 was less favorable than 4 . This resulting high energy intermediate may help explain the extremely high turnover frequency of this species $\left(>30 /\right.$ sec $^{7}{ }^{7}$

Roughly speaking, the structure of 6 resembles 4: the dihedral angles of C-C-O-Si in both structures are 180.0 degrees and the values of $\mathrm{A}(\mathrm{C}, \mathrm{O}, \mathrm{Si})$ are almost the same $\left(\mathbf{4} ; 129.1^{\circ}, \mathbf{6}\right.$; $\left.127.5^{\circ}\right)$. The Si-O distance in $6(1.694 \AA)$ is smaller than that of $4(1.881 \AA)$ and $\mathrm{A}(\mathrm{O}, \mathrm{Si}, \mathrm{C})$ of 6 $\left(107.1^{\circ} \sim 110.5^{\circ}\right)$ is larger than that of $4\left(100.3^{\circ} \sim 104.7^{\circ}\right)$. These results indicate that $\mathrm{Si}-\mathrm{O}$ bond of 6 has larger covalent character than that of 4 . With the same trend, the $\mathrm{Si}-\mathrm{O}$ bond of 5 has larger covalent character than that of $\mathbf{3}$ (compare $1.710 \AA$ for 5 vs $1.901 \AA$ for 3). Very notably, the structure for 5 is very unusual. The dihedral angle $(\mathrm{D}(\mathrm{C}, \mathrm{C}, \mathrm{O}, \mathrm{Si}))$ is 129.8 degrees (compared to $180^{\circ}$ in 6), showing that the $\mathrm{C}=\mathrm{C}$ bond and $\mathrm{Si}-\mathrm{O}$ bond are twisted towards each other. In addition, the structure of 5 suggests that one silicon atom has an interaction with $\mathrm{C}=\mathrm{C}$ double bond. Further comparing 5 and $\mathbf{6}$, the structures of the $\mathrm{CH}_{2}=\mathrm{CH}-\mathrm{O}$ portion are significantly different. The C-O bond length in 5 is larger than that of 6 (1.380 $\AA$ and $1.368 \AA$ respectively). This arises from a lesser extent of conjugation of lone pairs at oxygen with the $\mathrm{C}=\mathrm{C}$ double bond due to the twist structure. While the Si-O bond length of $5(1.710 \AA)$ was larger than that of 6 $(1.694 \AA)$, the total of angles around the central silyl atom in $5\left(\Sigma \mathrm{A}(\mathrm{O}, \mathrm{Si}, \mathrm{Si})=324.0^{\circ}\right)$ were almost same with the value in $6\left(\Sigma \mathrm{A}(\mathrm{O}, \mathrm{Si}, \mathrm{C})=324.7^{\circ}\right)$. This is the result of complex interactions in $\mathbf{5}$. The energy difference of two total values indicated that $\mathbf{5}$ was more favorable than 6 implying that the TTMSS group will also have a function of stabilizing the EE (Figure 3). 

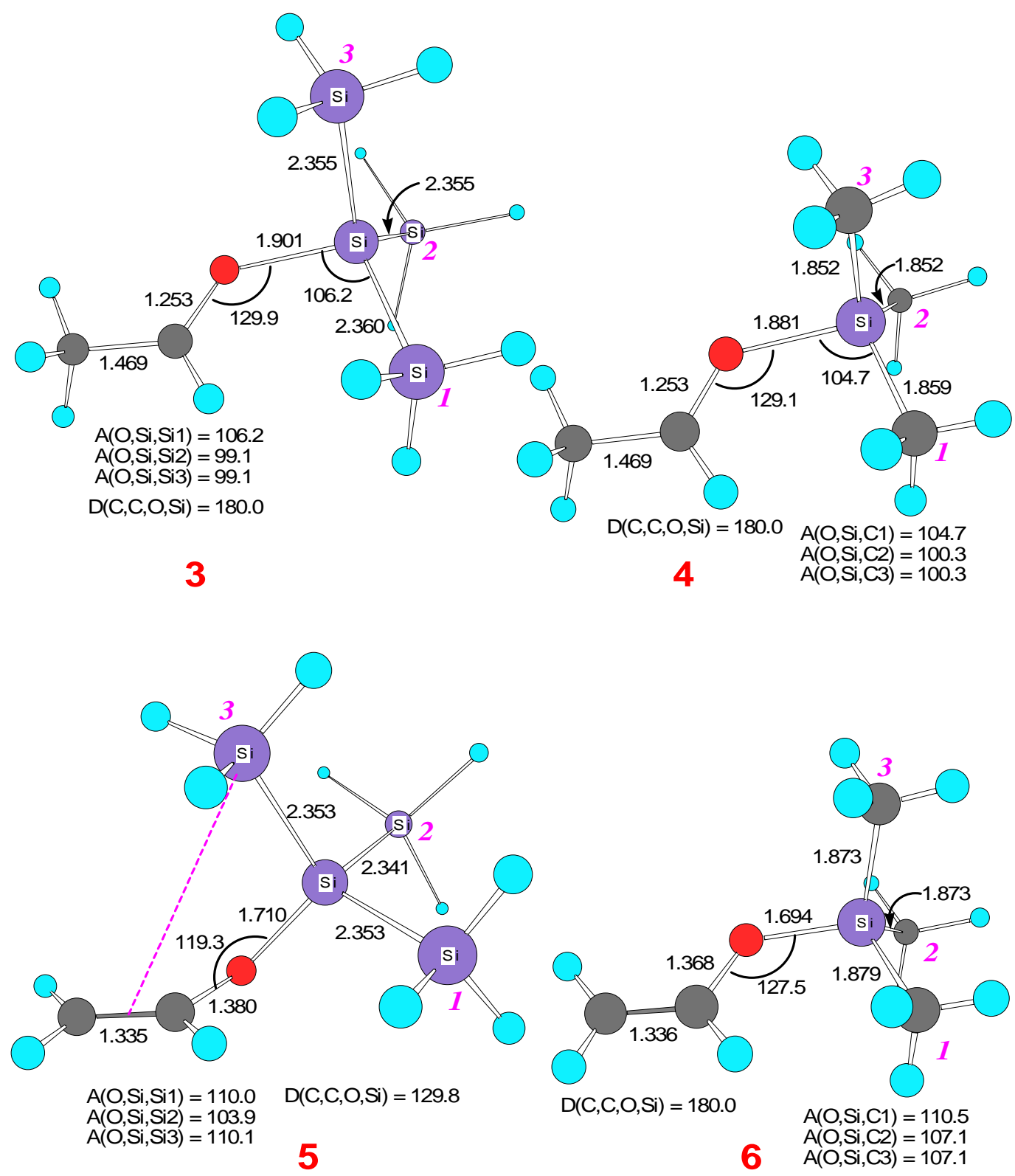

$$
\begin{aligned}
& \left(4+\mathrm{TTMSS}^{+}\right)-\left(3+\mathrm{TMS}^{+}\right)=-0.9 \mathrm{kcal} / \mathrm{mol} \\
& \left(6+\mathrm{TTMSS}^{+}\right)-\left(5+\mathrm{TMS}^{+}\right)=+2.9 \mathrm{kcal} / \mathrm{mol}
\end{aligned}
$$

Figure 2. Structures of the protonated species of SEE's (3 and 4) and neutral SEE's (5 and 6). Energy difference $(\mathrm{kcal} / \mathrm{mol})$ of $\left[\left(\mathbf{4}+\mathrm{TTMSS}^{+}\right)-\left(\mathbf{3}+\mathrm{TMS}^{+}\right)\right]$and $\left[\left(\mathbf{6}+\mathrm{TTMSS}^{+}\right)-\left(\mathbf{5}+\mathrm{TMS}^{+}\right)\right]$ are indicated for estimation of the stabilities of the species. 


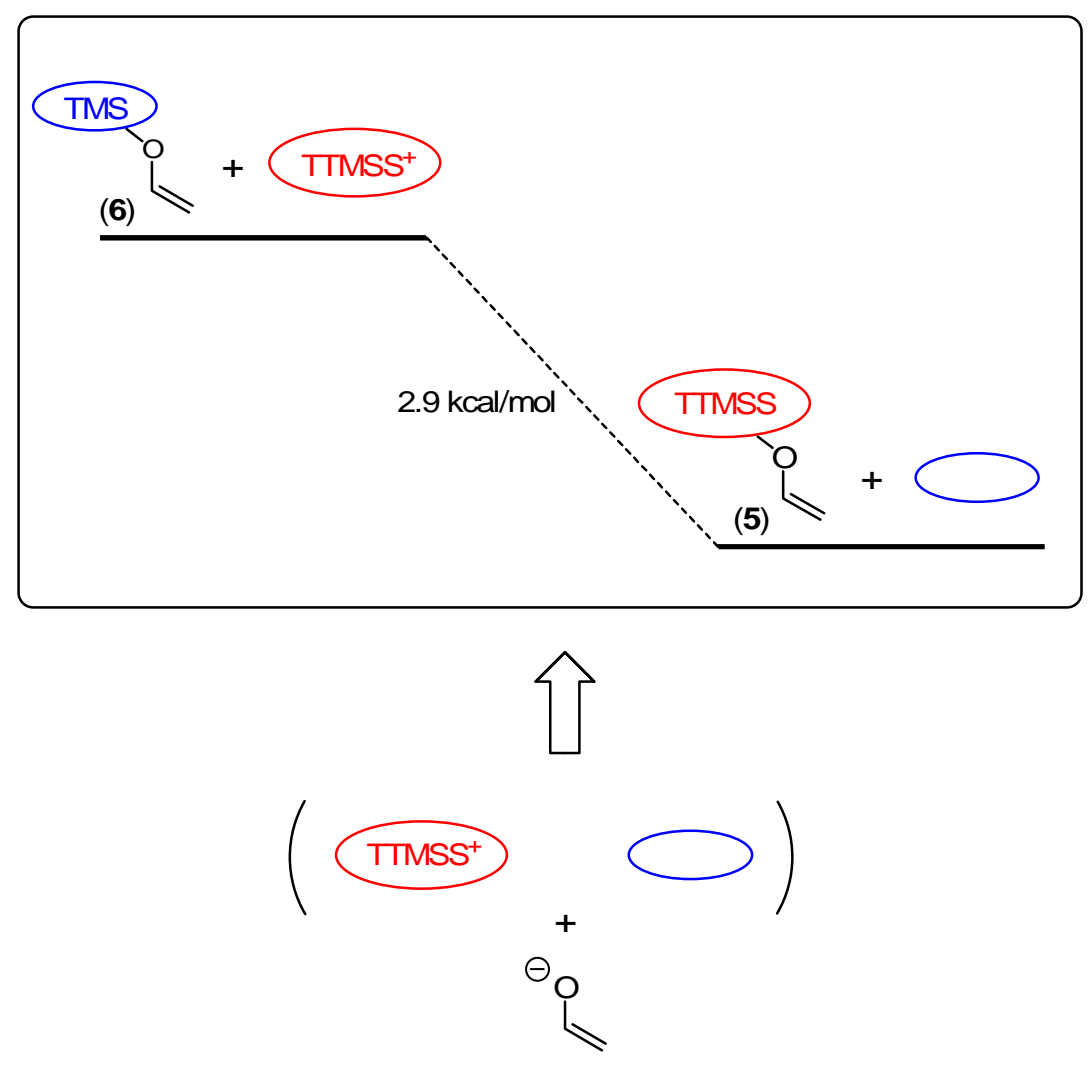

Figure $\mathbf{3 .} \mathbf{5}$ is more stable silyl enol ether than $\mathbf{6}$.

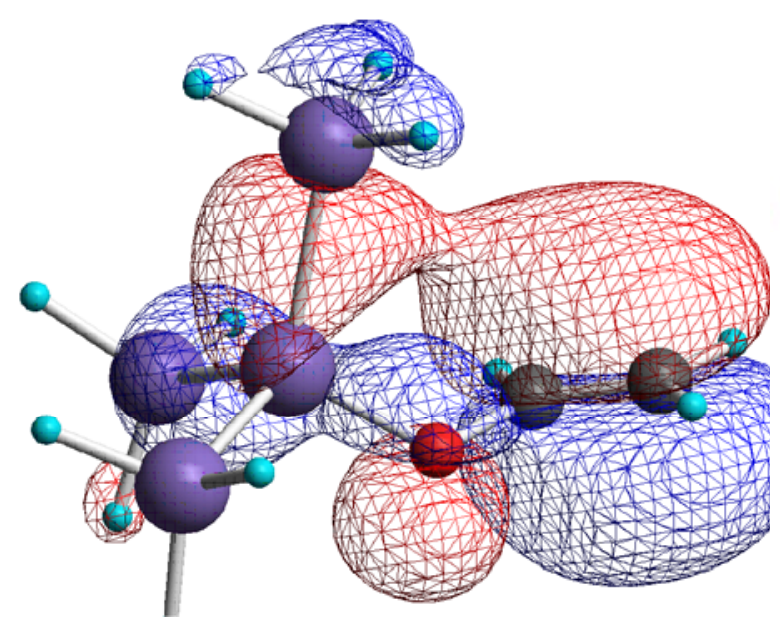

5

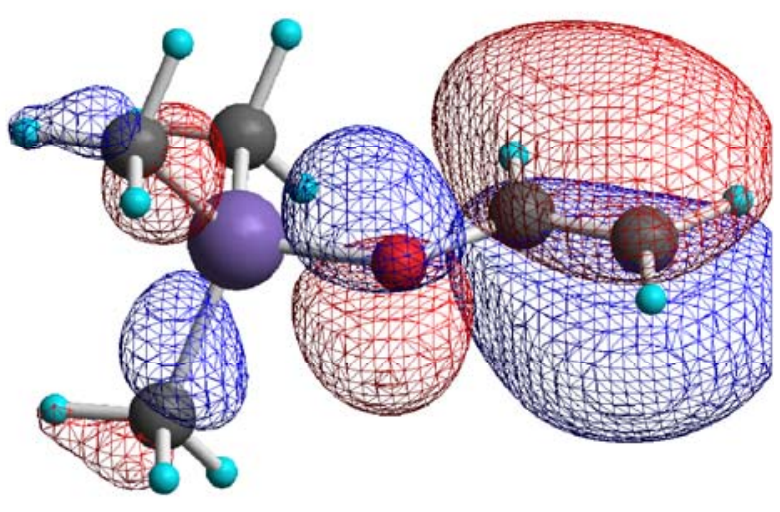

6

Figure 4. Graphical presentation of HOMO of 5 and 6.

The electron density of $\mathbf{5}$ and $\mathbf{6}$ were calculated and a substantial difference for the HOMO's was observed (Figure 4). While no orbital overlap exists between the silyl part and $\mathrm{CH}_{2}=\mathrm{CH}-\mathrm{O}$ portion in 6, there is orbital overlap between the silyl part and $\mathrm{CH}_{2}=\mathrm{CH}-\mathrm{O}$ part in the case of 5 . 
There is apparent overlap of the $\mathrm{Si}-\mathrm{Si} \sigma$-bond and the $\pi$-bond in $\mathrm{CH}_{2}=\mathrm{CH}-\mathrm{O}$. Interestingly, orbital overlap like this for a SEE has never been reported. There is also overlap of a Si-Si $\sigma$ bond and lone pair of oxygen in $\mathrm{CH}_{2}=\mathrm{CH}-\mathrm{O}$ part. It is reasonable to suppose that these orbital overlaps are one of the key factors in the unusual structure and the aforementioned stability of 5 as well as the unique selectivity observed in the aldol reactions with this substrate.

\section{Conclusions}

Models of plausible intermediates along the proposed mechanism have been probed. Interestingly, a single TMS group adjacent to a silicenium ion has a net stabilizing effect when compared to a $t$-Bu group. It is therefore believed that the super silyl cation, containing three $\alpha$ TMS groups would be a relatively stable species, capable of catalyzing the aldol reaction. This stability, as well as the relatively (compared to TMS) high energy intermediate produced when coordinated to an aldehyde supports the high turn over frequency observed. Although no detailed explanation can be made about the high selectivity seen in the aldol reactions, the twisted structure and unusual HOMO overlaps observed in the silyl enol may help to develop a model elucidating the source of these selectivities.

\section{Acknowledgements}

The authors would like to express special thanks to Professor Alain Krief for his many significant contributions to organic chemistry. The calculations were carried out at the Research Center for Computational Science (RCCS), Okazaki Research facilities, National Institutes of Natural Science (NINS).

\section{Computational Details}

Theoretical calculations were performed using the Gaussian $98^{8}$ and $03^{9}$ programs, at secondorder M $\phi 1 l e r-P l e s s e t$ perturbation theory $(\mathrm{MP} 2)^{10}$ with 6-31G(d,p) basis set.

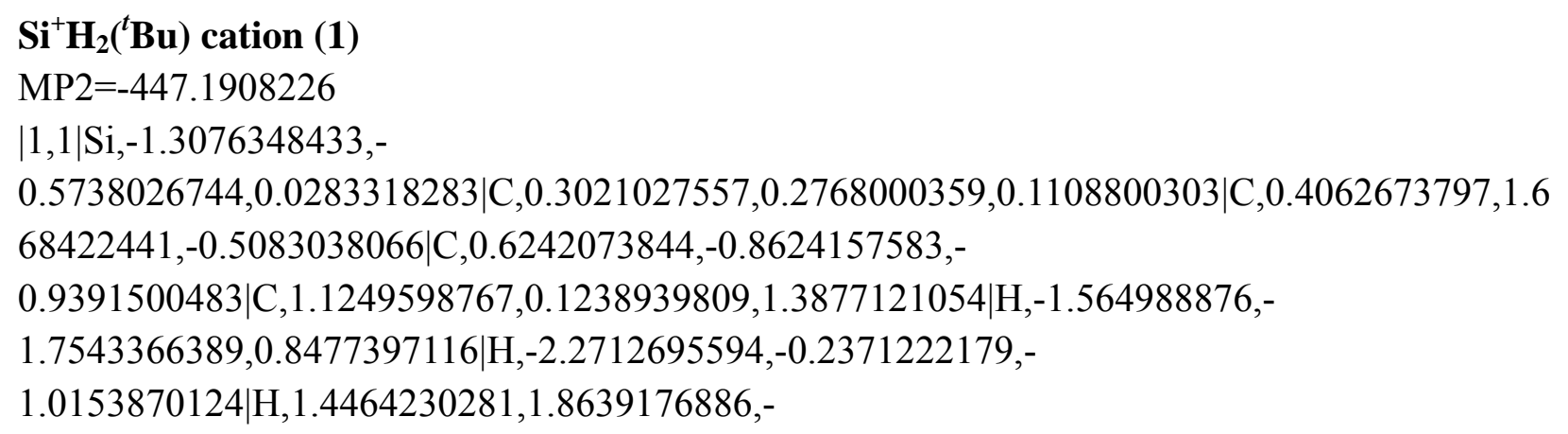


0.7699546084|H,0.0879189632,2.4235911599,0.2069985684|H,-0.1959632255,1.7721689082,$1.4104858518|\mathrm{H}, 0.8731487147,-0.4457074485,-1.9115410325| \mathrm{H},-0.2224884557,-$ $1.5756561843,-1.1976977144 \mid \mathrm{H}, 1.384974079,-1.5421204047,-$ $0.5644765923|\mathrm{H}, 2.1762248374,0.2958399074,1.1555747683| \mathrm{H}, 1.0327561428,-$ $0.8677800834,1.829833193|\mathrm{H}, 0.8149277784,0.8602385588,2.1259212908|$

\section{$\mathrm{Si}^{+} \mathrm{H}_{2}$ (TMS) cation (2)}

MP2=-698.2130916

|1,1|Si,-1.802168553,-0.6155483243,0.3515553283|Si,0.4332946055,0.1641357052,$0.0718832829|\mathrm{C}, 0.2403420173,1.8941531082,-0.7528318642| \mathrm{C}, 1.0311300931,-1.0900122847$,$1.3338928054|\mathrm{C}, 1.3173211288,0.0680334122,1.5722409726| \mathrm{H},-2.1787674137,-$ $1.6201933546,1.3576001349 \mid \mathrm{H},-2.9990048057,-0.2307126192,-$ $0.4118195101|\mathrm{H}, 1.231000747,2.2748427482,-1.0073509753| \mathrm{H},-0.1930505225,2.5809805475$,$0.0272960723|\mathrm{H},-0.3617244728,1.9193864955,-1.6599123217| \mathrm{H}, 2.0569205369,-$ $0.8237869479,-1.5973483316|\mathrm{H}, 0.449734761,-1.0758415091,-2.2547114156| \mathrm{H}, 1.0539533963$,2.1068366615,-0.9444306446|H,2.356325303,0.3657113887,1.4206909733|H,1.3236187354,$0.9405330062,1.9829380321|\mathrm{H}, 0.892469565,0.7437141712,2.3131336779|$

\section{$\mathrm{SiH}_{3}\left({ }^{\mathbf{B} u}\right)(\mathbf{1 - H})$ \\ $\mathrm{MP} 2=-448.0778689$ \\ |0,1|Si,0.158203621,0.2126288489,1.5010704508|C,-0.0388015553,-0.0520982464,- $0.3679348934|\mathrm{C},-1.0962052564,0.9136842401,-0.9140879916| \mathrm{C},-0.4795343055,-$ $1.4950247006,-0.6380403488|\mathrm{C}, 1.2996936265,0.2102954487,-1.0670268125| \mathrm{H}, 1.1806724825,-$ $0.7094989834,2.0426030128 \mid \mathrm{H},-1.1252729779,-$ $0.0423610954,2.1914741181|\mathrm{H}, 0.5784689633,1.6038790193,1.7786476941| \mathrm{H},-$ $1.2155620763,0.7668223309,-1.991066724|\mathrm{H},-0.8128016253,1.9547131443,-0.7508074394| \mathrm{H},-$ $2.0691060163,0.7508341552,-0.4475254683 \mid \mathrm{H},-1.4370370423,-1.718512758,-$ $0.1647600694|\mathrm{H}, 0.2544681427,-2.2150548771,-0.2726675637| \mathrm{H},-0.595034941,-$ 1.6552164867,-1.7135586098|H,1.1939481368,0.0597833671,-2.1449219039|H,2.0783455051,- $0.4670023401,-0.7125319096|\mathrm{H}, 1.6431456984,1.2336701895,-0.907331171|$}

\section{$\mathrm{SiH}_{3}$ (TMS) (2-H)}

MP2=-699.0985885

|0,1|Si,1.9425131681,-0.14356625,-0.0633001631|Si,-

$0.3968259507,0.0293404195,0.0129290531|\mathrm{C},-0.920619725,0.8680663357,1.6243348079| \mathrm{C},-$ $1.1653152226,-1.6960358059,-0.0711946641 \mid \mathrm{C},-1.0069959187,1.0565156154,-$ $1.4523674626|\mathrm{H}, 2.3892474582,-0.7974773122,-1.3149169553| \mathrm{H}, 2.456117516,-$ $0.9432632546,1.0728012789|\mathrm{H}, 2.578532171,1.1926800052,0.0004422738| \mathrm{H},-$ $2.0068837656,0.9545809596,1.6749643649|\mathrm{H},-0.5036650192,1.8717842298,1.7047629397| \mathrm{H},-$ $0.5920858222,0.2996599373,2.4942478749|\mathrm{H},-2.2537882,-1.6326248317,-0.0367363104| \mathrm{H},-$ 
$0.8424193218,-2.3167703753,0.7644018406 \mid \mathrm{H},-0.8917738923,-2.2090700715,-$ $0.993020736|\mathrm{H},-2.0940745866,1.1450090223,-1.4312595817| \mathrm{H},-0.7296382709,0.5994633203$,$2.4020766767|\mathrm{H},-0.5916041108,2.0639131262,-1.4330508607|$

\section{$\mathrm{CH}_{3} \mathrm{CH}=\mathbf{O}(\mathrm{TTMSS})^{+}$cation (3)}

$\mathrm{MP} 2=-1314.4424151$

$|1,1| \mathrm{C},-3.6058812622,-0.6855356531,0.1291165893 \mid \mathrm{C},-2.1498616018,-$ $0.8272338601,0.2638477679 \mid \mathrm{O},-1.3685117437,0.0809773858,-$ $0.1035020122|\mathrm{Si}, 0.5300409872,0.155007376,-0.043277614| \mathrm{Si}, 0.9661363543,0.4199267362,-$ 2.3423347239|Si,1.2403851955,$1.8864090048,0.9035058932|\mathrm{Si}, 0.7858676357,2.0564938572,1.3223545721| \mathrm{H},-3.980196152,-$ $1.5139231973,-0.4771175088|\mathrm{H},-3.8726407029,0.2692669698,-0.3110430295| \mathrm{H},-$ $4.0581704768,-0.8006577648,1.1170828986 \mid \mathrm{H},-1.7365529869,-$ $1.7437814258,0.6935856857 \mid \mathrm{H}, 2.4301172079,0.4612599432,-$ 2.4814864425|H,0.3345438741,1.6724366258,-2.7835171482|H,0.3894996015,-0.7462883598,$3.032368719|\mathrm{H}, 2.7080543413,-1.8041621103,0.9389660374| \mathrm{H}, 0.7747103668,-$ $2.9943019003,0.050576225 \mid \mathrm{H}, 0.6662659256,-$ $2.0094648083,2.2551781618|\mathrm{H}, 2.2340573442,2.2412217694,1.5038175333| \mathrm{H}, 0.112557457,1.7$ $688511168,2.6001034833|\mathrm{H}, 0.1662829167,3.1980756293,0.6329789927|$

\section{$\mathrm{CH}_{3} \mathrm{CH}=\mathrm{O}(\mathrm{TMS})^{+}$cation (4)}

$\mathrm{MP} 2=-561.5196967$

$|1,1| \mathrm{C}, 0.0351120169,1.0409585354,-3.0727036574 \mid \mathrm{C},-0.1998166771,0.2306184479,-$ $1.8706584643|\mathrm{O}, 0.2004586926,0.6013294596,-0.7429326853| \mathrm{Si}, 0.019174169,-$ $0.2576445658,0.9203006209|\mathrm{C}, 1.8008954092,-0.4665830593,1.3810936815| \mathrm{C},-0.9051423108,-$ $1.8260691053,0.5422192219 \mid \mathrm{C},-$ $0.9302229956,1.0284890384,1.8557497626 \mid \mathrm{H}, 0.584605709,0.4343801454,-$ 3.7965591502|H,0.5750056485,1.9521038007,-2.8392673366|H,-0.930140873,1.2642590752,$3.5333663304|\mathrm{H},-0.7351711252,-0.718283383,-1.9548758097| \mathrm{H}, 1.8684752915,-$ $0.9065469778,2.3770302113|\mathrm{H}, 2.3188760259,0.4906778086,1.4074519496| \mathrm{H}, 2.3259781342$,$1.1284995047,0.6941638885|\mathrm{H},-1.0399134503,-2.3689674176,1.479754412| \mathrm{H},-0.3612648303,-$ $2.4915268112,-0.1273127288|\mathrm{H},-1.901748084,-1.6481099676,0.139703017| \mathrm{H},-$ $1.0665141853,0.6998100672,2.8869692201|\mathrm{H},-1.9191534097,1.1957057403,1.4317461796| \mathrm{H},-$ $0.3960954133,1.9769025272,1.879612001$

\section{$\mathrm{CH}_{2}=\mathbf{C H}-\mathrm{O}$ (TTMSS) (5)}

$\mathrm{MP} 2=-1314.0831877$

|0,1|C,-2.0559420769,-2.6582679486,0.9127952954|C,-1.1281367069,-

$1.7391014923,1.1892894234 \mid \mathrm{O},-0.0790216816,-$

$1.4765236892,0.3322746271 \mid \mathrm{Si}, 0.2544823798,0.1401834318$,- 
0.1124681834|Si,1.0822327721,1.3649492784,1.718236137|Si,-1.6912324246,1.1676324693,$0.9417283623|\mathrm{Si}, 1.8910232364,-0.0601150541,-1.7745928943| \mathrm{H},-2.0297387873,-$

$3.212003712,-0.0131834755|\mathrm{H},-2.8345285713,-2.8668775142,1.6291914288| \mathrm{H},-$ $1.1261702317,-$

$1.177066772,2.1200576409|\mathrm{H}, 1.2498145811,2.7738110636,1.2997467864| \mathrm{H}, 2.3906967155,0.8$ $396004238,2.160045529|\mathrm{H}, 0.144610527,1.3216651138,2.8607969186| \mathrm{H},-$

$1.3058057374,2.455850493,-1.5598247321|\mathrm{H},-2.6621807732,1.4397145363,0.1381959446| \mathrm{H},-$ 2.33169764,0.3181462069,-1.9662754444|H,2.3391547021,1.29261987,-

2.1700696324|H,1.3422313299,-0.7478427359,-2.9604852849|H,3.0491765477,$0.8183125724,-1.2611547675$

\section{$\mathrm{CH}_{2}=\mathrm{CH}-\mathrm{O}(\mathrm{TMS})(\mathbf{6})$ \\ $\mathrm{MP} 2=-561.1545436$ \\ |0,1|C,2.323506811,-1.9434053543,1.1024420075|C,1.6980489421,- $0.9106246714,0.5315460956|\mathrm{O}, 0.3339626939,-0.8370995416,0.4553325541| \mathrm{Si},-$ $0.5949710532,0.4025336062,-0.231221882 \mid \mathrm{C},-1.6282784571,-0.3721204587,-$ $1.5875979823|\mathrm{C}, 0.5146909883,1.7480140908,-0.9306244377| \mathrm{C},-$ $1.6878919735,1.0881838701,1.1264332076 \mid \mathrm{H}, 3.4005529522,-$ $1.9592066302,1.1396785948|\mathrm{H}, 1.768833822,-2.7647899121,1.528448728| \mathrm{H}, 2.2455222325,-$ $0.0786855321,0.0997544561|\mathrm{H},-2.2994998348,0.3603509766,-2.0373695348| \mathrm{H},-2.236328331$,- $1.1862193967,-1.194885165|\mathrm{H},-0.9970763976,-0.7787453892,-2.3770519132| \mathrm{H},-$ $0.1015349522,2.5348523783,-1.367697739 \mid \mathrm{H}, 1.1702019857,1.3738724022,-$ \\ $1.7166805402|\mathrm{H}, 1.1357851656,2.2098420463,-0.1634784025| \mathrm{H},-$ $2.3601173882,1.8552207623,0.7402697139|\mathrm{H},-1.0914811916,1.5337064775,1.9219344752| \mathrm{H},-$ $2.2974227345,0.3008428035,1.5683298988$}

\section{References and Notes}

1. For reviews of aldol reaction see: (a) Nielsen, A. T.; Houlihan, W. J. In Organic Reactions, Adams, R.; Blatt, A. H.; Boekelheide, V.; Cairns, T. L.; Cram, D. J.; House H. O. Eds.; John Wiley \& Sons: New York, 1968; Vol 16. (b) Mukaiyama, T.; In Organic Reactions, Dauben, W. G.; Boswell G. A. Jr.; Danishefsky, S.; Gschwend, H. W.; Heck, R. F.; Hirshchmann, R. F.; Kende, A. S.; Paquette, L. A.; Posner, G. H.; Trost, B. M.; Bittman, R.; Weinstein, B. Eds.; John Wiley \& Sons Inc.; New York, 1982; Vol. 28, pp 203 - 331. (c) Heathcock, C. H. In Comprehensive Organic Synthesis, Trost, B. M.; Fleming, I. Eds., Pergamon Press: Oxford, 1991; Vol 2. pp 133 - 238 (d) Gennari, C. In Comprehensive Organic Synthesis, Trost, B. M.; Fleming, I. Eds.; Pergamon Press: Oxford, 1991; Vol. 2; pp 629 - 660. (e) Mahrwald, R. Chem Rev. 1999, 99, 1095. (f) Modern Aldol Reactions, Mahrwald, R.; WileyVCH Verlag GmbH \& Co.; Germany, 2004, Vol. 1 \& 2. 
2. "Super silyl” was coined by Hans Bock: Bock. H.; Meuret, J.; Ruppert, K. Angew. Chem. Int. Ed. Engl. 1993, 32, 414.

3. Boxer, M. B.; Yamamoto, H. J. Am. Chem. Soc. 2006, 128, 48.

4. Lambert, J. B.; Zhao, Y.; Emblidge, R. W.; Salvador, L. A.; Liu, X.; So, J.-H.; Chelius, E. K. Acc. Chem. Rev. 1999, 32, 183.

5. Apeloig, Y.; The Chemistry of Organic Silicon Compounds, Patai, S.; Rappoport, Z. Eds., John Wiley \& Sons: New York, 1989; Part 1, pp $184-200$.

6. Optimization of $+\mathrm{CH}_{2}-\mathrm{C}\left(\mathrm{CH}_{3}\right)_{3}$ and $+\mathrm{CH}_{2}-\mathrm{Si}\left(\mathrm{CH}_{3}\right)_{3}$ gave the rearranged cations $\left(\left(\mathrm{CH}_{3}\right) \mathrm{CH}_{2}-\right.$ $\mathrm{C}+\left(\mathrm{CH}_{3}\right)_{2}$ and $\left.\left(\mathrm{CH}_{3}\right) \mathrm{CH}_{2}-\mathrm{Si}+\left(\mathrm{CH}_{3}\right)_{2}\right)$.

7. Determined by ${ }^{1} \mathrm{H}$ NMR experiment performed at room temperature, which showed complete conversion in less than 1 minute.

8. Frisch, M. J.; Trucks, G. W.; Schlegel, H. B.; Scuseria, G. E.; Robb, M. A.; Cheeseman, J. R.; Zakrzewski, V. G.; Montgomery, J. A., Jr.; Stratmann, R. E.; Burant, J. C.; Dapprich, S.; Millam, J. M.; Daniels, A. D.; Kudin, K. N.; Strain, M. C.; Farkas, O.; Tomasi, J.; Barone, V.; Cossi, M.; Cammi, R.; Mennucci, B.; Pomelli, C.; Adamo, C.; Clifford, S.; Ochterski, J.; Petersson, G. A.; Ayala, P. Y.; Cui, Q.; Morokuma, K.; Malick, D. K.; Rabuck, A. D.; Raghavachari, K.; Foresman, J. B.; Cioslowski, J.; Ortiz, J. V.; Stefanov, B. B.; Liu, G.; Liashenko, A.; Piskorz, P.; Komaromi, I.; Gomperts, R.; Martin, R. L.; Fox, D. J.; Keith, T.; Al-Laham, M. A.; Peng, C. Y.; Nanayakkara, A.; Gonzalez, C.; Challacombe, M.; Gill, P. M. W.; Johnson, B.; Chen, W.; Wong, M. W.; Andres, J. L.; Gonzalez, C.; Head-Gordon, M.; Replogle, E. S.; Pople, J. A. Gaussian 98; Gaussian, Inc.: Pittsburgh, PA, 1998.

9. Frisch, M. J.; Trucks, G. W.; Schlegel, H. B.; Scuseria, G. E.; Robb, M. A.; Cheeseman, J. R.; Montgomery, J., J. A.; Vreven, T.; Kudin, K. N.; Burant, J. C.; Millam, J. M.; Iyengar, S. S.; Tomasi, J.; Barone, V.; Mennucci, B.; Cossi, M.; Scalmani, G.; Rega, N.; Petersson, G. A.; Nakatsuji, H.; Hada, M.; Ehara, M.; Toyota, K.; Fukuda, R.; Hasegawa, J.; Ishida, M.; Nakajima, K.; Honda, Y.; Kitao, O.; Nakai, H.; Klene, M.; Li, X.; Knox, J. E.; Hratchian, H. P.; Cross, J. B.; Adamo, C.; Jaramillo, J.; Gomperts, R.; Stratmann, R. E.; Yazyev, O.; Austin, A. J.; Cammi, R.; Pomelli, C.; Ochterski, J. W.; Ayala, P. Y.; Morokuma, K.; Voth, G. A.; Salvador, P.; Dannenberg, J. J.; Zakrzewski, V. G.; Dapprich, S.; Daniels, A. D.; Strain, M. C.; Farkas, O.; Malick, D. K.; Rabuck, A. D.; Raghavachari, K.; Foresman, J. B.; Ortiz, J. V.; Cui, Q.; Baboul, A. G.; Clifford, S.; Cioslowski, J.; Stefanov; Liu, G.; Liashenko, A.; Piskorz, P.; Komaromi, I.; Martin, R. L.; Fox, D. J.; Keith, T.; Al-Laham, M. A.; Peng, C. Y.; Nanayakkara, A.; Challacombe, M.; Gill, P. M. W.; Johnson, B.; Chen, W.; Wong, M. W.; Gonzalez, C.; Pople, J. A. GAUSSIAN 03 Revision C02; Gaussian, Inc.: Pittsburgh PA, 2003.

10. (a) Frisch, M. J.; Head-Gordon, M.; Pople, J. A. Chem. Phys. Lett. 1990, 166, 275. (b) Frisch, M. J.; Head-Gordon, M.; Pople, J. A. Chem. Phys. Lett. 1990, 166, 281. (c) Pople, J. A.; Krishnan, R.; Schlegel, H. B.; Binkley, J. S. Int. J. Quant. Chem., Quant. Chem. Symp. 1979, 13, 325. (d) Handy, N. C.; Schaefer, H. F. III Chem. Phys. 1984, 81, 5031. 